\title{
Social Accountability for Local Government in Ghana
}

\section{Dr. Rudith S. King}

Centre for Settlements Studies

Kwame Nkrumah University of Science and Technology, Kumasi, Ghana Email: rudithk@gmail.com

\section{Amponsah Owusu}

Department of Planning,

Kwame Nkrumah University of Science and Technology, Kumasi, Ghana

Email: papa.owusu.amponsah@gmail.com
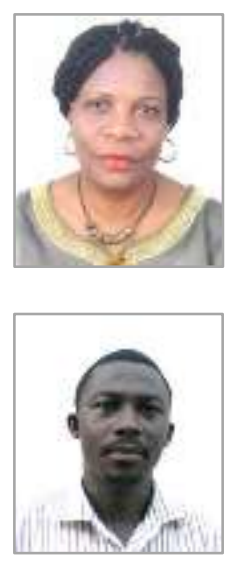

\section{Imoro Braimah}

Department of Planning

Kwame Nkrumah University of Science and Technology, Kumasi, Ghana Email: ibraimah2002@gmail.com

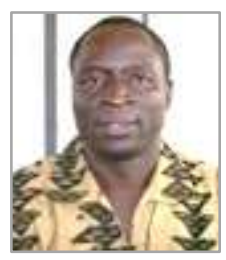

\begin{abstract}
Social accountability is considered as one strategy of deepening Ghana's decentralised development administration. Some attempts have been made to empower local people to demand transparency and accountability from the local government system as required by law. The purpose of this paper was to assess the effectiveness of these attempts in 14 Metropolitan and Municipal Assembles. The data for the analyses were sought through key informant interviews with core Assembly staff, and focus group discussions with selected Assembly Members. The analyses revealed that the legal provisions made room for social accountability but the weak capacity of Assembly Members in terms of resources, the understanding of legislative provisions,

and the acceptability of the concept challenged its implementation. It is thus recommended that service provision in local communities should have capacity-building components that promote social accountability.
\end{abstract}

Keywords: Social accountability, local government, district assemblies, Public finance management, civil society, Ghana

\section{Introduction}

The notion of good governance as a necessary condition for sustainable development and poverty reduction has gained widespread currency, especially among international organisations and industrialised world nations (Punyaratabandhu, 2004, World Bank, 2007). Indeed, good governance has become a condition for development assistance from development partners (DP). 
According to Hallak and Poisson (2006) and Sebudubudu (2010), the notion of good governance has several tenets of which transparency and accountability are key. The term 'governance' is defined as:

a set of values and principles that underpin state-society relations. This means allowing people, in particular the poor and marginalized, to have a say in how they are governed, in how decisions are made and implemented, in how diverging opinions are mediated and conflicting interests are reconciled in a predictable fashion and in accordance with the rule of law (Lister 2010, 6).

Accordingly, governments all over the world have introduced a variety of conventional mechanisms, also known as horizontal accountability mechanisms - political, fiscal, administrative and legal - to engender transparency and accountability in the administration and management of public offices (UNDP, 1998; Malerna et al, 2004). Examples of political mechanisms include checks and balances offered by government and investigative commissions, auditing and financial accounting; these are essential fiscal mechanisms for ensuring transparency and accountability in the administration and management of public offices. Administrative mechanisms are evident in public sector codes of conduct, rules and procedures, while the legal mechanisms include corruption-control agencies and ombudsmen, among others.

Despite these efforts, the institutionalisation of the conventional mechanisms in the administration of public funds has yielded modest results in ensuring accountability and transparency of public office holders to the grassroots (World Bank, 2006; Yilmaz et al, 2008). Transparency International (2009) attributes the weak checks and balances to the corrupt practices of office holders. The ramifications have been the misapplication of public funds, financial malfeasance and lack of sustainability in planned interventions resulting in the slow pace of poverty reduction in many developing countries. Social accountability has thus emerged as a response to the weaknesses of the conventional accountability mechanisms. Accountability is an important building block in social accountability and the lack of it can lead to a crisis of legitimacy amongst citizens and their governments (Malena et al, 2004). Accountability is affected where there are weak checks and balances, lack of separation of power and absence of rule of law (World Bank, 2011).

The World Bank (2006) defined social accountability to mean: 'the broad range of actions and mechanisms (beyond voting) that citizens can use to hold the state into account, as well as actions on the part of government, civil society, media and other social actors that promote or facilitate these efforts' (2006:3). Malerna et al. (2004) also define social accountability as 'an approach towards building accountability that relies on civic engagement, i.e., in which it is ordinary citizens and/or civil society organizations who participate directly or indirectly in exacting accountability' (pg. 3). From these definitions, social accountability suggests using a 'bottom-up' approach to demand accountability that is demand-driven, that requires the availability of the structures and laws that define people's rights, and the extent to which they can go in exacting accountability from duty bearers. The significance of social accountability relies on providing a common platform on which different actors, including communities, private sector (e.g. service providers), civil society 
organisations, government, media, etc., can work together to ensure local governments respond to the needs of the poor. Engaging in social accountability requires having certain skills, which cannot be taken for granted or assumed. It requires a conscious effort to build people's capacity to demand accountability and transparency from public office holders.

Accountability processes are both horizontal and vertical, described by Ackerman (2004) as 'proactive process by which public officials inform and justify their plans of action, their behaviour, and results and are sanctioned accordingly' in which horizontal processes of accountability involve external involvement of another party (2004: 3). In the case of social accountability, ordinary citizens contribute to enhance horizontal accountability processes. Social accountability thus has a core relationship to sustainable development in supporting good governance and empowerment towards poverty reduction. Social accountability should however not be viewed in isolation from the conventional horizontal mechanisms to engender accountability, but as complementary in ensuring accountability from public office holders, and therefore, an accountability framework that combines citizen-led accountability mechanisms and the horizontal ones for achieving more effectiveness.

According to Malena (2004), the building blocks of social accountability are:

- Identifying an entry point e.g.: budget allocations or performance of service provider,

- Building an evidence base through compiling relevant public information which can either be supply-side government data or demand-side users' data,

- Public dissemination of findings through public meetings, events or the media,

- Building coalitions to initiate collective action, and

- Advocacy with public officials to bring change.

The building blocks show that engaging in social accountability requires certain basic skills including data collection, analysis and interpretation; budget analysis and interpretation; and advocacy, lobbying and negotiation skills, which very often ordinary community members expected to engage in social accountability may not have.

\section{Decentralisation and Social Accountability in Ghana}

Ghana introduced decentralisation in 1988 with the ultimate purpose of supporting participatory governance and improving service delivery and financial management to facilitate the achievement of a rapid socio-economic development (Ohene-Konadu, 2001). The local government structure is outlined in Figure 1 below. 


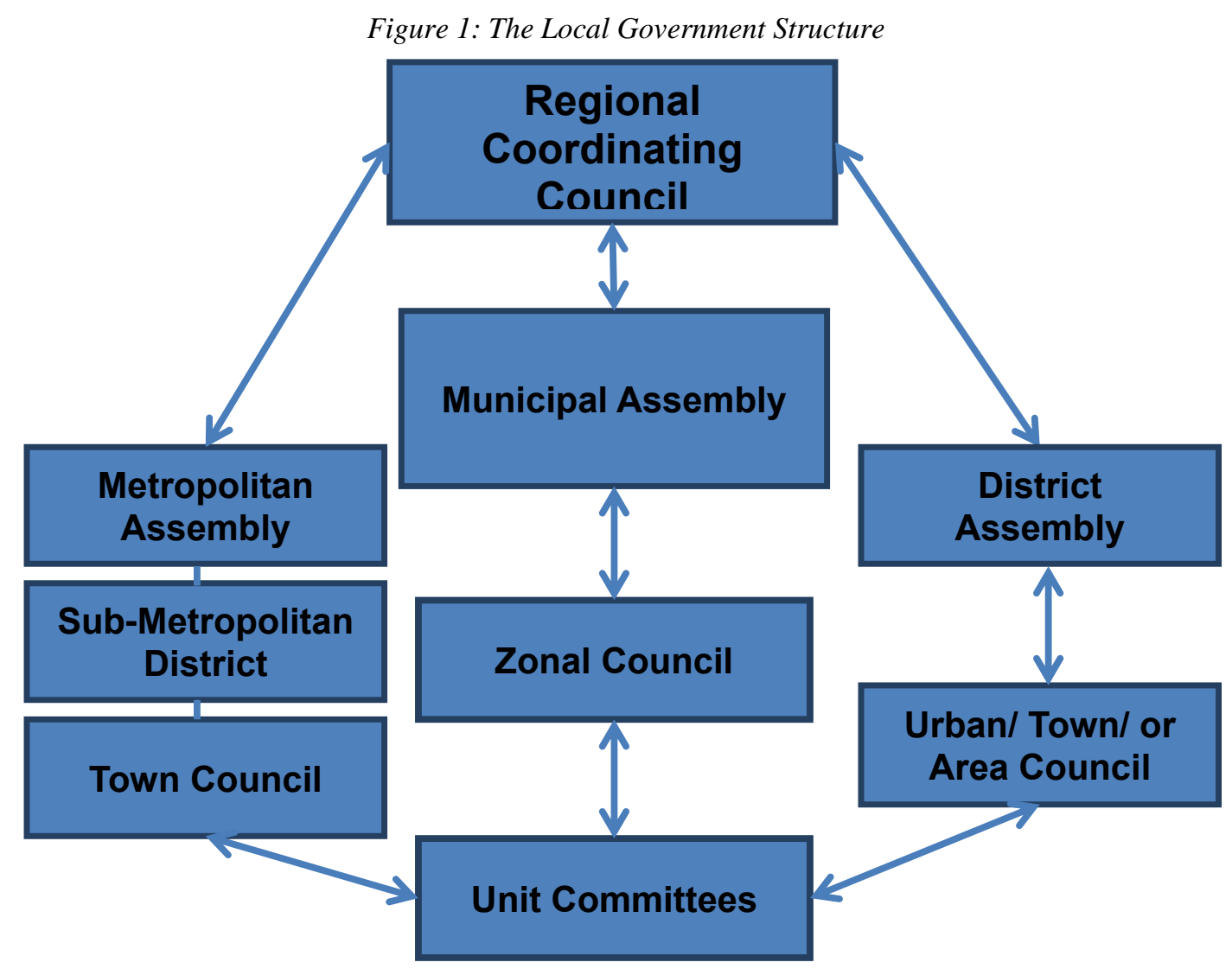

Source: Introduction to Ghana’s Local Government System, ILGS, 2008

Emphasis has been on the involvement of communities in efforts to reduce poverty, generate growth and ensure central and local government accountability to citizens (NDPC, 2003). The decentralisation programme is anchored in six inter-related pillars: political decentralisation; administrative decentralisation; fiscal decentralisation; decentralised planning; market decentralisation and spatial decentralisation, underpinned by three interrelated strategies of transfer of power, competence and means (Cofie-Agamah, 2003; Wold Bank, 2003). The resources which accompany the transfer of power and competences from the centre to the Metropolitan, Municipal and District Assemblies (MMDAs) must be administered in a transparent and accountable manner. The fiscal decentralisation pillar however has not been fully implemented, due to the low capacity of the MMDAs to manage newly decentralised funds.

The World Bank (2003) maintained that Ghana's decentralisation programme was not fully implemented. For decentralisation to reduce poverty, generate growth and ensure accountability there must be the full transfer of power, competences and resources to the MMDAs to perform the numerous roles enshrined in the Local Government Act 1993, Act 462. This implies the need to ensure that the MMDAs have the capacity to manage the funds transferred to them, and that they are accountable to both citizens and central government to forestall mismanagement, misapplication and financial malfeasance that will inhibit local socio-economic and spatial development. 
Informed by the necessity to ensure the required competence in the management of public funds, the Ministry of Local Government and Rural Development (MLGRD) aimed to embed social accountability in the use of public funds at the local level, and to ensure that people who are affected by planned interventions have the right and capacity to demand accountability and transparency from local politicians and administrators. Active civic engagement in development planning is seen as having a kingpin role in sustainable public financial management, a recipe for effective poverty and inequality reduction.

Social accountability in the use of public funds in Ghana is thus underpinned by a legislative framework that demands compliance by all actors. Based on this premise, this paper seeks to analyse the following questions:

- Are local actors aware of the rights and responsibilities enshrined in the national constitution and Local Government Act 462 to demand accountability from service providers?

- Do people affected by planned interventions have the capacity to demand accountability and transparency from local public office holders and service providers and, if so, is it happening?

- What is the level of compliance by the MMDAs with legislative provisions that seek to ensure prudent financial administration and management at local government level?

\section{Scope and methodological approach}

This paper investigates the attempts being made by local governments to improve public finance management through civic engagement in social accountability. The data are drawn from interviews with local government officials in 14 Metropolitan and Municipal Assemblies covering nine regions of Ghana that benefited from capacity building in social accountability provided by the MLGRD ${ }^{15}$. The Community Based Rural Development Project (CBRDP) emphasised capacity building for communities and Area Councils ${ }^{16}$ to perform their statutory roles in planning and managing community-driven initiatives. The CBRDP aimed at resourcing rural communities through local government structures to improve their socio-economic status and deepen local participation in governance $^{17}$.

Two methodological approaches were employed to analyse the issues which address the research questions; desk and field studies. The desk study involved a brief review of local government legislation and policy, and project documents of the Government of Ghana. Horizontal accountability mechanisms reviewed as part of the legislative framework for social accountability in public finance

\footnotetext{
${ }^{15}$ Three people each in 168 of the 216 MMDAs were trained in the use of the social accountability tools.

${ }^{16}$ Area councils are lower level sub-structures of the local governments in Ghana.

${ }^{17}$ The trainees received training in the use of social accountability tools including how to conduct public expenditure tracking surveys, the use of citizen report cards and community scorecards, forming local oversight committees, conducting public opinion polls, among others.
} 
management include the Local Government Act 1993 (Act 462), the National Development Planning Systems Act (Act 480), the Public Procurement Act (Act 663), and the Internal Audit Act 2003.

The field study was undertaken in three Metropolitan Assemblies and 11 Municipal Assemblies ${ }^{18}$ (Table 1). Using semi-structured questionnaires, qualitative data were collected from key local government stakeholders in the selected Assemblies through key informant interviews and focus group discussions (Table 2). Stakeholders included the assemblies' core staff, Assembly Members and Area Council chairpersons. The core staff at the Assemblies includes Chief Executives, Coordinating Directors ${ }^{19}$, Finance Officers, Planning Officers and Engineers.

Table 1: Metropolitan and Municipal Assemblies surveyed

\begin{tabular}{|l|l|}
\hline Region & Metropolitan/Municipal Assembly \\
\hline Greater Accra & $\begin{array}{l}\text { Accra Metropolitan Assembly, } \\
\text { Ashaiman Municipal Assembly }\end{array}$ \\
\hline Volta & Keta Municipal Assembly \\
\hline Upper West & Wa Municipal Assembly \\
\hline Upper East & Bolgatanga Municipal Assembly \\
\hline Western & Secondi-Takoradi Metropolitan Assembly \\
\hline Eastern & $\begin{array}{l}\text { Birrim Central Municipal Assembly } \\
\text { Kwahu West Municipal Assembly }\end{array}$ \\
\hline Central & $\begin{array}{l}\text { Cape Coast Municipal Assembly } \\
\text { Komenda/Edina/Eguafo/Abirem Municipal Assembly }\end{array}$ \\
\hline Brong Ahafo & $\begin{array}{l}\text { Sunyani Municipal Assembly } \\
\text { Techiman Municipal Assembly }\end{array}$ \\
\hline Ashanti & $\begin{array}{l}\text { Kumasi Metropolitan Assembly } \\
\text { Asante Akim North Municipal Assembly }\end{array}$ \\
\hline
\end{tabular}

Table 2: Number of stakeholders Interviewed

\begin{tabular}{|l|c|}
\hline Stakeholders Interviewed & No of stakeholders Interviewed \\
\hline Chief Executive & 9 (out of 14) \\
\hline Assembly members & 28 \\
\hline Engineers & 14 \\
\hline Planning Officers & 14 \\
\hline Finance Officers & 14 \\
\hline Coordinating Directors & 7 (out of 14) \\
\hline Area Council Chairpersons & 28 \\
\hline Total Number of Stakeholders Interviewed & 114 \\
\hline
\end{tabular}

A total of 114 of 126 key stakeholders were interviewed, including the principal planning and finance officers in all the 14 Assemblies due to their centrality in project and financial management. Additionally, there were 8 focus group discussions in four Assemblies where there was evidence of on-going or completed projects in which local people were involved. (Plate1). The focus groups consisted of members from communities that had benefited from government or other interventions.

\footnotetext{
18 The local governments in Ghana are referred to as assemblies, with the metropolitan assembly being the largest in terms of size, followed by the municipality and then the district assemblies.

19 The coordinating directors are the administrators that work for the local governments.
} 
The following section first discusses core sections of the legislation that promote social accountability before discussing the findings from the interviews.

\section{Legislative provisions in Ghana with social accountability components}

\section{Constitution of the Republic of Ghana}

The Constitution of the Republic of Ghana, 1992, makes provisions for civic engagement in decisionmaking including the use of public funds, and stresses the importance of participation, transparency and accountability in their administration. The Directive Principle of State Policy 35 (6d) in the Constitution decentralises the administrative and financial machinery of government to the local level by affording all possible opportunities to the people to participate in decision-making. Furthermore, Chapter 24, 240 (2d) requires people in local government service to subject themselves to the control of local authorities. Similarly, Chapter 24, 240 (2e) requires local government authorities to be accountable to the local population who should be afforded the opportunity to participate in local governance. The social accountability provisions in the Constitution complement a provision that requires the Auditor General to audit the accounts of the Assemblies annually and submit its audit reports to Parliament. Internal auditors are also in place to ensure that the management of public funds complies with provisions in the law.

\section{Local Government Act (Act 462) 1993}

The Local Government Act (Act 462) of 1993 establishes and regulates the local government system in accordance with the Constitution. Decentralisation is generally expected to promote greater transparency, accountability, probity and efficiency in public services provision, and to incorporate local needs and conditions, and national objectives for the planning and delivery of public services (Keith and McCluskey, 2004).

The Act makes provisions for effective and efficient management of public funds. Section 10 (subsection 3a) of the Local Government Act requires Assemblies to be responsible for the overall development of their areas, and to ensure the preparation and submission of their Assembly development plans and budgets through the Regional Coordinating Councils (RCCs) to the National Development Planning Commission (NDPC) and the Ministry of Finance and Economic Planning (MOFEP). Similarly, Section 11 of the Act makes the Assemblies responsible for the preparation and approval of its annual budget. Section 87 (sub-section 2) requires that moneys from the District Assembly Common Fund (DACF) received by the Assembly should only be spent on projects in the approved development plan.

Section 120 (sub-sections 2 and 3) of Act 462 requires that every Assembly should have an internal audit unit whose head is responsible to the General Assembly. The need for an internal audit is stressed by the Internal Audit Act (Article 16a). The head of the Internal Audit is required to audit the 
Assemblies' accounts every three months and supply the Presiding Member $^{20}$ with his/her reports. The Auditor General (or an auditor approved by him/her) must audit the Assemblies annually and send the reports to the Minister, Parliament and Assembly (Section 121 (sub-section 1)). Section 121 (sub-section 4) of the Local Government Act mandates Assemblies to consider the audit reports from the auditors at their ordinary meetings.

The Act also states the composition of the Metropolitan/Municipal Assemblies. Section 5 (b) of the Act mandates the election of one person from each electoral area by universal adult suffrage in accordance with the Electoral Commission's regulations. Sections 21 (f) and 21 (v) require the executive committee (whose membership does not exceed one-third of the total number of Assembly Members, elected by the members from among themselves) to monitor and evaluate all policies, programmes and projects. Though Members of Parliament (MPs) do not have voting rights, they must be present at Assembly meetings. Assembly Members are also on Metropolitan/Municipal Tender Boards (Section 39 of Act 462).

The Assembly Members are required by Section $16(\mathrm{a}-\mathrm{j})$ to maintain close contact with their constituents and to relay Assembly discussions to their constituents for their feedback. Thus, constituents are represented in the Assemblies by their elected representatives, and could be said to be participating in local governance including financial management because their views are represented.

\section{National Development Planning (System) Act (Act 480), 1994}

The National Development Planning (System) Act (Act 480) of 1994 defines and regulates planning procedures in Ghana. The Act gives project beneficiaries the mandate to participate in the identification, selection and prioritisation of their development needs. The rationale is to ensure local ownership of planned interventions (Sections 3 and 4), which implies participating in the selection, costing and supervision of planned interventions. Sub-district authorities are required to prepare local action plans, or sub-district plans, and submit them for approval to the District Planning Authority (Section 5, sub-sections 1 and 3) which may be incorporated into the Assemblies' medium term development plans.

\section{Public Procurement Act (Act 663), 2003}

The Public Procurement Act (Act 663) of 2003 ensures transparency in the use of public funds for procurement. The Act seeks to harmonise the processes of procurement in the public sector to ensure judicious, economic and efficient use of public resources in public procurement. It also ensures that public procurement is carried out in a fair, transparent and non-discriminatory manner.

\footnotetext{
${ }^{20}$ The Presiding Member is the corporate head of the Assembly. He calls for Assembly meetings and presides over the General Assembly meeting.
} 
Section 17 (sub-section 1) of the Act mandates central management agencies, Ministries, Departments and Agencies, subvented agencies and others to establish a Tender Committee. The Committee should consist of the Director of Finance, a lawyer appointed by the MMDA, one Member of Parliament; and three heads of Departments one of whom represents the user department or agency. The Tender Committees should ensure transparency in procurement of goods, services or works through public funds.

Section 17 (sub section 2) requires public office holders to ensure that every stage of the procurement activity and procedures set out in the Public Procurement Act are followed. They are also required to exercise sound judgment in making procurement decisions, and refer any procurement above the approval threshold to the appropriate Tender Review Board. Section 20 (d) mandates Assemblies to establish Tender Review Boards to oversee public procurement.

\section{Internal Audit Agency Act (Act 658), 2003}

This Act establishes an Internal Audit Agency as a central agency responsible for the coordination, facilitation, monitoring and supervision of internal audit activities within MDAs and MMDAs. The overall objective of this Act is to secure quality assurance and application of standards of internal audit within these state institutions, and to ensure accountability and transparency of state institutions.

Article 16 of the Act requires the Assemblies to establish autonomous internal audit units to ensure effective and efficient auditing of their accounts. Sub-section 4 of Section 16 of the Internal Audit Agency Act (Act 658) of 2003 requires the Internal Auditor to submit audit reports to all stakeholders including the Auditor General, the Regional Coordinating Councils (RCCs) and the Assemblies. The Assemblies' Audit Report Implementation Committees, established under Section 30 (sub-section 1) of the Audit Service Act (Act 584) of 2000 are responsible for implementing the recommendations of the internal audit reports. Thus, the Act makes provisions for financial prudence at the Assembly level in line with the concept of social accountability.

\section{Operationalisation of the Legal/Legislative Provisions: fieldwork findings}

Data from the interviews showed that Metropolitan and Municipal Assemblies involve beneficiaries of planned interventions in project identification, design, implementation, and monitoring and evaluation in line with the legal provisions. Assembly Members are involved in budget approval and tracking, and are informed through Assembly meetings and Chief Executives' sessional addresses of any DACF, ceded revenue and other transfer payments to the Assemblies by the central government or development partners. The funds are used to finance approved development projects and programmes with the General Assembly having the right to question any misuse and diversion of funds. 
The Audit Report Implementation Committees receive audit reports from internal auditors which are discussed with Assembly Members at assembly meetings. The Audit Report Implementation Committee is charged with the responsibility of implementing recommendations in audit reports.

There are, however some weaknesses in the implementation of this legal provision. The Presiding Member of the Assembly has no defined role in the Internal Audit Agency Act (Act 658) of 2003, nor in the Public Procurement Act (Act 633) in relation to his/her roles in the assembly. There is an ineffective involvement of citizens or the public who are the beneficiaries of the planned interventions in the financial management process, and Assembly Members who have to liaise between the central administration and constituents complained about low financial and logistical capacity to reach their constituents. Thus, contributions at Assembly meetings on effective public financial management largely represent the views of the Assembly Members. The Assembly Members indicated that in Metropolitan/Municipal Assemblies with dispersed populations and poor accessibility it becomes impossible for the Assembly Members to visit communities regularly and to engage them in Assembly decisions. It requires for example, hiring vehicles to go to remote areas, perhaps only in the dry season when the roads are accessible. Assembly Members are not entitled to transport allowance, so travel becomes difficult in municipalities that have rural communities with poor accessibility. Thus, providing feedback becomes difficult for some Assembly Members. The legal requirements become an additional cost to Assembly Members, which they are not prepared to incur as individuals, and the Assemblies do not cover such additional expenses.

Analyses of the data from the Metropolitan and Municipal Assembly interviews showed that Assembly Members play an active role in the local public financial management (PFM), and play pivotal roles in preparing and approving Assembly budgets. Furthermore, the General Assembly rectifies anomalies in the Assemblies' accounts identified by both the Auditor-General and Internal Auditors. The Assembly Members also ensure that the DACF is used for projects earmarked in development plans. Also, the Chief Executives at their sessional address inform Assembly Members of the amounts to be transferred to the Assemblies from the DACF. As required by Section 121, all the Metropolitan/Municipal Assemblies surveyed publicise their annual statement of accounts, and any other report from the Auditor-General, three months after the close of the financial year. In some of the Assemblies visited such as Techiman Municipal Assembly, this was pasted on the notice board for the information of the general public.

Nevertheless, there are challenges in terms of skills and resources of Assembly Members, including the inability of Assembly Members to give regular feedback to their constituents on Assemblies' proceedings because of limited financial and logistical support from the Assembly/government. However, Assembly Members are the elected local representatives of the local people and are 
expected to serve their interest. Providing feedback to constituents requires having a good means of communicating with constituents which is lacking.

Additionally, the exclusion of Assembly Members from contract awarding limits the Assembly Members in demanding accountability from contractors on development projects. This was seen by all the Assembly Members interviewed as a critical weakness in their attempt to demand accountability from service providers. Thus, active participation of the constituents in the management of the Assemblies' funds is limited by competency, financial and logistic constraints. Election of Assembly Members, it was noted from the interviews, is sometimes done without considering the competencies of candidates, who may be elected based on their local popularity, generosity or other factors not related to their competency in local governance.

The interviews revealed continued weak capacity of Assembly Members although the situation seems to be gradually improving. Of the 21 (out of 28) Coordinating Directors and Planning Officers interviewed, $72 \%$ of them said very few Assembly Members actually appreciate their roles and responsibilities because of their literacy levels. The roles and responsibilities are set out in the relevant legal instruments such as the Local Government Act (Act 462), the Constitution and the Public Procurement Act (Act 663). This challenge makes it difficult for many of the Assembly Members particularly those with only basic level education to critically examine decisions of the Assembly. Others are unable to understand the legal provisions that guide them as a result of limited background training, such as teachers and informal traders. In addition, the Assemblies have few financial resources to train Assembly Members and rely on the limited capacity-building programmes of the MLGRD. With these weaknesses Assembly Members are unable to question anomalies, and are unable to demand accountability from duty bearers.

Although the interviews showed that project beneficiaries participate in the identification and prioritisation of development projects in line with the guidelines on preparation of the Assemblies' Medium Term Development Plans, this takes place in a very mechanistic manner to meet the requirements of the NDPC, with limited time for a rigorous participatory planning process. Interviewees also said that most of the sub-administrations are unable to prepare plans for incorporation into the Medium Term Development Plans due to weak capacity. For example, within Techiman Municipality only four of the 10 Area Councils have prepared their action plans. Similarly, in Sunyani Municipal Assembly, only two out of the six Area Councils had prepared action plans. Most of the Area Councils which have been able to prepare action plans received training under the Community Based Rural Development Project (CBDP), which suggests that local capacity building is important in enhancing the work of the Assemblies. 
Evidence from the interviews also indicated that social accountability can be very effective at the community level, and citizen engagement is more effective when people appreciate the concept and are able to apply it. Explaining expenditure made by service providers and the challenges they encounter is also better appreciated by citizens when they have experience in preparing action plans and the principles of social accountability, thereby also making the work easier for service providers (Plate 1). Where problems were explained to community members, they were more than happy to suggest alternative solutions to help the service providers, as observed in the Asante Akim North Municipal Assembly. It was also observed that involvement of citizens in the practice of social accountability helped to inform community members about standards for basic community services. They were thus able to confront service providers when shoddy work was done. In the Asante Akim North Municipal Assembly, for example, women in one community said they confronted the contractor working on their culverts because they felt the shoddy job he was doing could become death traps for their children who were likely to fall into open culverts.
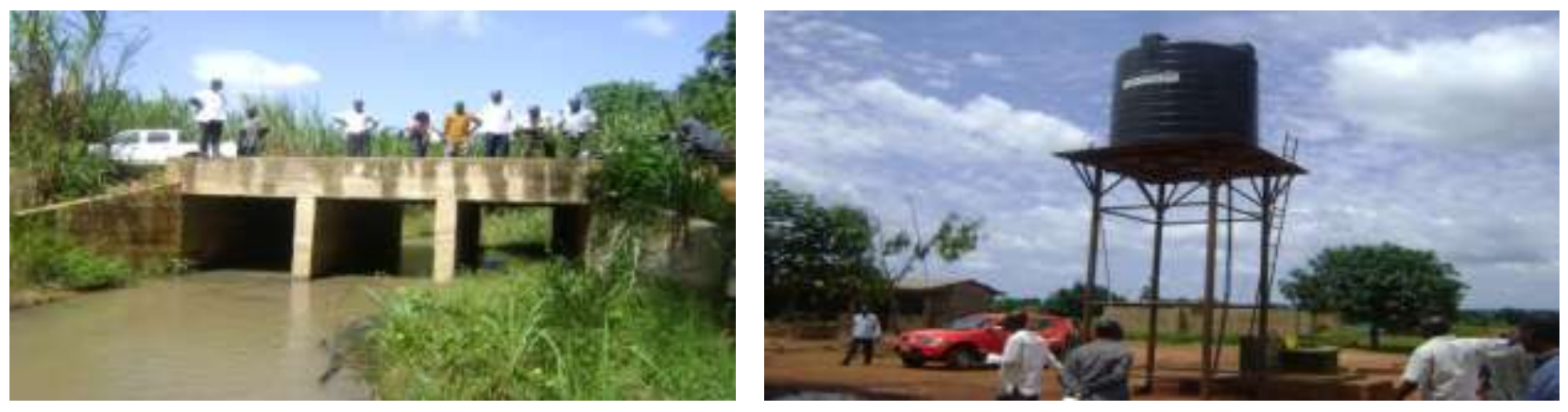

Plate 1: Project implemented with the principles of social accountability

The interviews in Sekondi-Takoradi Metropolis showed that through the application of social accountability mechanisms community members have seen the successful implementation of development projects (Plate 1). It has also helped to improve the relationship between service providers (teachers, community health workers, etc.) and beneficiaries. Thus, the application of the social accountability concept can be a win-win situation for all parties in ensuring effective public finance management if only communities are trained in social accountability and its implications.

With regards to procurement of goods and services, all the Metropolitan and Municipal Assemblies studied had Tender Committees in place as prescribed in the Act to oversee procurement of goods, services and works for the Assemblies. Procurement plans and their updates are submitted to the Tender Committees after budget approval at quarterly intervals.

However, it was noted that there are still some weaknesses in accountability through the procurement process. Contractors are not accountable to Assembly Members who also do not account to their electorates in the execution of contracts in their electoral areas, as they are not represented on the Tender Committees, especially at the stage of contract award. Their non-representation robs them of the details of the contracts (standards and specifications) which would help them to ensure effective 
monitoring of contracts implementation. This was expressed as a major concern by all the Assembly Members interviewed, and this weakness in Assembly procurement practices encourages the service providers to deliver shoddy goods and services. In a focus group discussion with community members at Asante Akim North Municipal Assembly, one of the participants said:

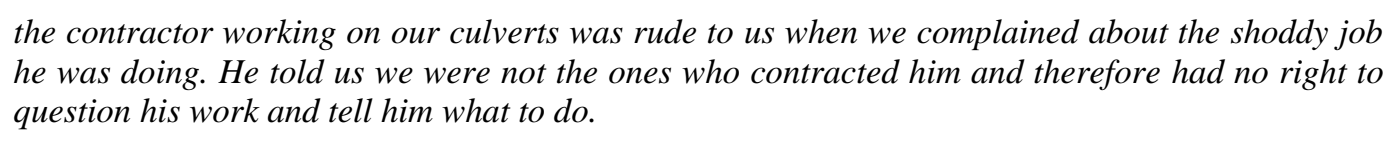

With regards to auditing, all the Metropolitan and Municipal Assemblies interviewed had autonomous Audit Units. Internal Auditor audits the Assembly accounts every quarter and they submit their reports to the RCCs and the Assemblies. The interview results showed that all the Assemblies had established Audit Report Implementation Committees with the Presiding Members as the chairpersons. The Assemblies are required to justify anomalies reported in the audit reports and where the justifications are unreasonable, sanctions are applied to the affected persons.

However, as noted earlier, due to the low capacities of the Assembly Members, their constituents are rarely informed about the outcome of an audit. This limits the accountability of public officers in the financial management process to horizontal accountability to the RCC and the Auditor General, and no vertical accountability is achieved. Presiding Members also have no defined roles as the chairmen of the Audit Report Implementation Committees in the Internal Audit Act (Act 633).

\section{Challenges to promoting social accountability at local government level}

The attempt to enhance and promote social accountability through citizen involvement to ensure transparency and accountability, as is expected of decentralisation, is not without challenges. The Constitutional and legal provisions have not been effective due to the low capacity of Assembly Members to engage their constituents and provide them with regular feedback from the Assembly and solicit their views to take back to the Assemblies. Engaging in social accountability also requires skills and practice for experience, which even those who have been trained in it are yet to develop.

While decentralisation offers anyone the opportunity to participate, Assembly Members require an appreciable level of educational, competency and knowledge of the legal instruments and public administration to be able to work efficiently in the local government system.

Accessibility came out as one major constraint that hindered effective participation of community members in deliberations on public finances of local interventions. Of the 28 Assembly Members interviewed, $89 \%$ said that it is expensive to visit all their constituencies especially those in remote rural areas. Such communities are therefore cut off from participating effectively in local governance matters including monitoring of public finance. 
It was found that enforcement of the legal provisions could not ensure effective public management. Local governments are often unable to enforce legal provisions due to unclear roles of stakeholders, lack of cooperation from the law enforcement agencies, little understanding of these provisions, and the weak capacity of some of the core assembly staff, community members, Assembly Members and other stakeholders at district level. The weak and underdeveloped nature of the sub-assembly structures may also inhibit effective use of the legal provisions aimed at preventing financial malfeasance in order to reduce poverty and inequality. This situation is also compounded by the weak civil society organisations at community level in the 14 Assemblies visited. Though active in urban areas, community organisations are sparse at the sub-assembly level and are rarely engaged in governance activities. Thus, the further away one moves from the urban centres the weaker the activities and effectiveness of civil society that is considered as a key component in the application of social accountability mechanisms. The lack of strong civil society organizations in local communities to drive the social accountability agenda and to get the concept institutionalized is a major challenge for ensuring accountability at the Assemblies.

Generally, citizens are also ignorant about their role in ensuring local accountability and transparency, which became apparent through implementing the CBRDP in the 14 Assemblies. According to some of the participants who benefited from capacity building in the CBRDP and had to pilot social accountability skills, particularly the use of community score cards at on-going project sites, they encountered some antagonism from service providers and had to spend inordinate amount of time explaining the positive side of the exercise to the service providers. Thus, social accountability could be perceived as witch-hunting or punishment if not well communicated. There is the perception among service providers and even some Assembly staff that social accountability is meant to witchhunt opponents and hence there is a lack of commitment to the process. This further points to limited awareness creation and the need for capacity building at all levels to make decentralisation achievable.

\section{Recommendation and conclusions}

From the discussions above, it can be concluded that while a fairly good horizontal accountability has been achieved in Ghana's decentralised administrations, there is weak vertical accountability due to various factors including weak sub-structures and weak capacity of those expected to promote social accountability. As mentioned earlier, vertical accountability requires external involvement of other participants, a role that citizens and civil society organisations are expected to play.

Social accountability is still fairly new at all local government levels, and therefore awareness about this mechanism is new to many, including Assembly staff. The paper shows that only very few people benefited from capacity building in this new mechanism of improving public finance management; more people need to be aware of the process before the full benefits can be realised and Assemblies 
will have to invest in the process. However, Metropolitan and Municipal Assemblies are complying with the legal provisions to ensure prudent financial management but in a mechanistic manner, and often excluding lower tier organisations so only the vertical accountability appears to be working.

Based on the above, it is recommended that any intervention for local communities at the local government level should have capacity building for social accountability as a component, to empower citizens to play active roles in monitoring interventions and demanding accountability from the service providers to ensure efficient public finance management and ultimately, to achieve the goals of decentralisation and poverty reduction.

\section{References}

Ackerman, J. M. (2004) Social Accountability in the Public Sector; A Conceptual Discussion. http://siteresources.worldbank.org/INTPCENG/214574-1116506074750/20542263/FINALAckerman.pdf (accessed 20 June 2013)

Cofie-Agama, J. (2003) Fiscal Policy and Growth in Africa: Fiscal Decentralisation Ghana's Experience: Lessons and Issues. ECA

Hallak, J. and Poisson, M. (2006) Governance in Education: Transparency and Accountability. Paris, International Institute for Education Planning. http://mirror.undp.org/magnet/Docs/speeches/Sp2.htm. (accessed 18 January, 2011)

Keith, S. and McCluskey, W. (2004) Decentralization and Rural Property Taxation. FAO Land Tenure Studies. FAO: Rome

Lister, S. (2010) Fostering Social Accountability: From Principle to Practice - A Guidance Note. New York: United Nations Development Programme

Malena, C, Forster, R. and Singh, J. (2004) Social Accountability: An Introduction to the Concept and Emerging Practice. Washington: The World Bank, Social Development Paper No. 76.

National Development Planning Commission (NDPC) (2003) Ghana Poverty Reduction Strategy 2003-2005, An Agenda for Growth and Prosperity- Simplified Version. State Press, Accra

Ohene-Konadu, G. (2001) Gender Analysis and Interpretation of Barriers to Women's Participation in Ghana's Decentralised Local Government System, A Paper Presented at African Gender Institute, University of Cape Town, South Africa

Punyaratabandhu, S. (2004) Commitment to Good Governance, Development, and Poverty Reduction: Methodological Issues in the Evaluation of Progress at National and Local Levels. A Paper Prepared for the Sixth Session of the Committee on Development Policy, March 29 - April 2, 2004

Sebudubudu, D. (2010) The impact of good governance on development and poverty in Africa: Botswana - A relatively successful African initiative, African Journal of Political Science and International Relations, 4(7): 249-262

Transparency International (2009) Corruption and Human Rights: Making the Connection. Switzerland, International Council on Human Rights Policy

UNDP (1998) Adjusting the Role of Governments to Globalization, a statement to the Second Committee in October 27, 1998, accessed from http://mirror.undp.org/magnet/Docs/speeches/Sp2.htm (accessed 18 May 2013)

World Bank (2003) World Development Report 2004: Making Services Work for Poor People, World Bank and Oxford University Press, Washington, D.C.

World Bank (2006) Social Accountability Sourcebook. Washington, DC: World Bank

World Bank (2007) Source Book on Social Accountability: Strengthening the Demand Side of Governance and Service Delivery. Washington: World Bank 
World Bank (2011) Supporting Social in the Middle East and North Africa: Lessons Learned from Past Political and Economic Transitions. Washington: The World Bank

Yilmaz, S., Beris, Y. and Serrano-Berthet, R. (2008) Local Government Discretion and Accountability: A Diagnostic Framework for Local Governance in the Social Development Papers Local Governance \& Accountability Series Paper No. 113 / July 2008. Accessed http://siteresources.worldbank.org/EXTSOCIALDEVELOPMENT/Resources/2443621164107274725/3182370-1164201144397/3187094-

1173195121091/SD Working Paper_113.pdf?resourceurlname=SD Working_Paper_113.pdf (accessed 25 January 2011).

\section{Legislation}

1992 Constitution of the Republic of Ghana

The Internal Audit Agency Act, 2003

The Local Government Act 1993, Act 462

The National Development Planning System Act 1994 (Act 480)

The Public Procurement Act 2003, Act 663 